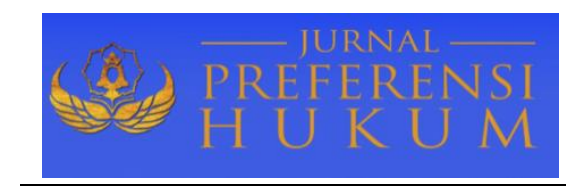

Jurnal Preferensi Hukum | ISSN: XXXX | E-ISSN: XXXX

Vol. 1, No. 2 - September 2020, Hal. 106-110| Available Online at https://www.ejournal.warmadewa.ac.id/index.php/juprehum

DOI: http://doi.org/10.22225/jph.v1i2.2382.106-110

\title{
PERSETUJUAN KELUARGA SEBAGAI SYARAT DALAM PEMBERIAN PEMBEBASAN BERSYARAT KEPADA NARAPIDANA
}

\author{
Gusti Ngurah Agung Tresna Wangsa, I Ketut Sukadana, I Made Budiyasa \\ Fakultas Hukum Universitas Warmadewa, Denpasar-Bali, Indonesia
}

\begin{abstract}
Abstrak
Salah satu hak terpidana adalah mendapatkan pembebasan bersyarat. Untuk mendapatkan haknya sebagai terpidana untuk mendapatkan pembebasan bersyarat dibutuhkan persetujuan dari keluarga terpidana sebagai penjamin. Penelitian ini bertujuan untuk mengetahui pengaturan pembebasan bersyarat bagi terpidana dan untuk mengetahui peran keluarga sebagai penjamin dalam pemberian pembebasan bersyarat bagi terpidana. Metode penelitian yang digunakan adalah jenis penelitian hukum normatif. Pendekatan masalah adalah pendekatan pendekatan konseptual dan perundang-undangan. Sumber bahan hukum primer dan sekunder. Pengumpulan bahan hukum dengan membaca atau mempelajari buku peraturan perundang-undangan dan literatur lainnya serta ditambah dengan hasil wawancara. Analisis bahan hukum dilakukan secara deskriptif analitik. Hasil dan pembahasannya adalah pengaturan pembebasan bersyarat diberikan kepada terpidana yang telah menjalani tindak pidana paling sedikit 2/3 (dua pertiga) dengan ketentuan 2/3 (dua pertiga) dari masa pidana paling sedikit. 9 (sembilan) bulan. hal itu diatur dalam Peraturan Pemerintah No. 99 Tahun 2012, Peraturan Menteri Hukum dan Hak Asasi Manusia, Peraturan Menteri Hukum dan Hak Asasi Manusia Nomor M.01.PK.04-10 Tahun 2007, Peraturan Menteri No. 21 Tahun 2013 yang berisi tentang syarat dan tata cara praperadilan bersyarat bagi terpidana. Persetujuan keluarga sebagai penjamin merupakan salah satu syarat wajib dalam memberikan pembebasan bersyarat kepada terpidana karena keluarga akan bertanggung jawab dalam membimbing dan mengawasi terpidana jika sudah mendapatkan Ayat Bersyarat, memberikan informasi tentang keadaan terpidana dan Keluarga juga wajib membantu kondisi ekonomi karena pada umumnya para terpidana yang baru memperoleh pembebasan bersyarat tersebut belum memiliki pekerjaan.
\end{abstract}

Kata Kunci: Keluarga; Narapidana; Pemberian Bebas Bersyarat

\begin{abstract}
One of the rights of convict is obtaining parole. To get his right as a convict in order to get parole requires the consent of the convict's family as a guarantor. The aims of the research are to know the arrangement of parole to the convicts and to know the role of the family as a guarantor in granting parole to convicts. The method of research is the type of normative legal research. Approach of problem is approach of conceptual approach and legislation. Primary and secondary legal materials are the data used in the study. Collection of legal materials by reading or studying books of legislation and other literature and added with the results of interviews. The analysis of legal materials is done by analytical descriptive. Results and discussion is the regulation of parole shall be granted to a convict who has served a criminal offense of at least 2/3 (two-thirds) with the provisions of 2/3 (two-thirds) of the criminal period not less than 9 (nine) months. It is regulated in Government Regulation no. 99 of 2012, Regulation of the Minister of Justice and Human Rights, Regulation of the Minister of Justice and Human Rights Number M.01.PK.04-10 of 2007, Ministerial Regulation no. 21 of 2013 which contains conditional pretrial conditions and procedures for convicts. Approval of the family as a guarantor is one of the mandatory requirement in granting conditional exemption to the convict because the family will be responsible in guiding and supervising the convict if they have obtained the Conditional Paragraph, providing information about the circumstances of the convicts and the family is also obliged to assist the economic condition because in general the convicts the newly acquired parole has not had a job yet.
\end{abstract}

Keywords: Family; Convict; Parole Granting 


\section{PENDAHULUAN}

Angka kejahatan di Indonesia semakin meningkat hal tersebut dikarenakan faktor perekonomian masih banyak masyarakat di Indonesia berada di bawah garis kemiskinan, hal tersebutlah yang memicu semakin banyaknya aksi kejahatan di Indonesia. Setiap pelaku kejahatan akan dipidana sesuai dengan ketentuan pidana yang berlaku. Di dalam UU No. 12/1995 mengenai Pemasyarakatan mengatur tentang berbagai hak untuk setiap narapidana yang sehendaknya dipenuhi, untuk mencapai tujuan pemasyarakatan sesuai dengan amanat yang tertuang pada undang-undang tersebut (Datunsolang, 2013; Kusuma, 2013). Setiap narapidana mempunyai hak yang harus diperhatikan, Undang-Undang Pemasyarakatan mengatur mengenai hak-hak seorang narapidana (Utami, 2017). Salah satunya tertuang dalam Pasal 14 ayat (1) huruf k menyatakan dengan tegas bahwa salah satu hak yang harus diperoleh dan dipenuhi untuk seorang narapidana yakni untuk mendapatkan pembebasan bersyarat.

Untuk mendapatkan haknya sebagai narapidana agar bisa mendapatkan pembebasan bersyarat perlu adanya kesanggupan dari pihak keluarga narapidana sebagai penjamin untuk memberikan bantuan untuk membimbing serta mengawasi narapidana saat menjalankan proses pembebasan bersyarat, beserta persetujuan kelian dinas atau kepala desa setempat (Jufri \& Anisariza, 2018; Putra \& Puspita Sari, 2013). Namun dalam kenyataan di masyarakat, pihak keluarga sebagai penjamin dan kelian dinas atau kepala desa setempat dimana domisili narapidana yang akan mengajukan pembebasan bersyarat menolak terjadinya pembebasan bersyarat yang diberikan kepada narapidana dikarenakan tindak pidana yang pernah dilakukan oleh narapidana yang akan mendapatkan pembebasan bersyarat.

Berdasarkan latar belakang masalah yang telah dijabarkan di atas, maka penelitian ini bertujuan untuk mengetahui pengaturan pembebasan bersyarat kepada narapidana, dan untuk mengetahui peran keluarga sebagai penjamin dalam pemberian pembebasan bersyarat kepada narapidana.

\section{METODE PENELITIAN}

Adapun metode penelitian yang digunakan dalam penelitian ini adalah tipe penelitian hukum normatif (Soekanto, 2007). Pengkajian penulisan dilakukan berdasarkan bahan-bahan hukum dan literatur dan merupakan proses didalam menemukan aturan-aturan hukum, serta norma-norma hukum demi menyelesaikan suatu permasalahan hukum yang dihadapi. Pendekatan masalah yang digunakan yakni pendekatan konseptual dan perundang-undangan. Sumber bahan hukum yang dipergunakan dalam penelitian ini merupakan sumber Bahan hukum primer dan sekunder, bahan hukum primer tersebut dapat diperoleh dari peraturan perundang-undangan sebagai yakni: Undang-Undang Dasar Negara Republik Indonesia Tahun 1945, KUHP, Undang-Undang No. 12 Tahun 1995 tentang Pemasyarakatan, Peraturan Pemerintah No. 99 Tahun 2012 tentang Perubahan Kedua Atas Peraturan Pemerintah No. 32 Tahun 1999 tentang Syarat dan Tata Cara Pelaksanaan Hak Warga Binaan Pemasyarakatan, Peraturan Menteri Hukum dan Hak Asasi Manusia Republik Indonesia No. 21 Tahun 2013 tentang Syarat dan Tata Cara Pemberian Remisi, Asimilasi, Cuti Mengunjungi Keluarga, Pembebasan Bersyarat, Cuti Menjelang Bebas, dan Cuti Bersyarat, dan peraturan lainnya yang berhubungan dan berkaitan dengan permasalahan. Bahan hukum sekunder yang digunakan dalam penelitian ini yakni literatur-literatur dengan mengutip pendapat yang relevan, ensiklopedi, majalah-majalah, internet. Bahan hukum tersebut di atas akan didukung hasil wawancara dengan informan yakni Kepala Balai Pemasyarakatan pada Balai Pemasyarakatan Kelas I Denpasar. Bahan hukum dikumpulkan dengan menginventarisasi, mempelajari bahan-bahan yang terkait yakni bahan hukum primer dan sekunder yang dilakukan dengan cara mencatat dan mengutip setiap buku atau literatur yang sesuai dengan permasalahan yang diteliti, dikaitkan dengan jenis penelitian hukum normatif, maka teknik pengumpulan bahan hukum dimulai dengan mengkaji peraturan perundangundangan mengenai pembebasan bersyarat serta ditambahkan dengan hasil wawancara dengan informan yakni Kepala Balai Pemasyarakatan pada Balai Pemasyarakatan Kelas I Denpasar.

Bahan-bahan hukum yang telah terkumpul dan telah dianalisis dapat menjadi jawaban yang tepat dan sesuai dengan permasalahan yang ditangani, perlu juga suatu teknik analisa yang tepat. Analisa adalah suatu langkah untuk mengolah hasil dari penelitian agar dapat menjadi sebuah laporan, setelah menjadi bahan hukum selanjutnya dikaji dan dianalisis secara sistematis dengan menggunakan 
argumentasi hukum serta penafsiran interpretasi secara deduktif, induktif dan hasil yang telah dikaji serta dianalisis tersebut disajikan secara deskristif analisis. kemudian dianalisis serta secara sistematis dengan cara argumentasi hukum dan penafsiran interpretasi secara deduktif dan hasilnya kemudian disajikan secara deskriptif analitis.

\section{HASIL DAN PEMBAHASAN}

\section{Pengaturan Pembebasan Bersyarat kepada Narapidana}

Kata "pembebasan bersyarat" atau "pelepasan bersyarat" dalam bahasa Belanda disebut: Voorwaardelijk Invrijheids Stelling dan dalam bahasa Inggris disebut Parole (Samosir, 2016). Tujuan dari pemberian pembebasan bersyarat kepada narapidana adalah pembinaan untuk membangkitkan semangat dan motivasi bagi seorang narapidana untuk bertobat dan berkelakuan baik demi tercapainya tujuan pembinaan. Selain hal tersebut tujuan lainnya yakni untuk mengurangi jumlah narapidana yang sedang berada di dalam Lembaga Pemasyarakatan yang pada umumnya sudah melebihi kapasitas. Dengan adanya pemberian pembebasan bersyarat bagi narapidana bertujuan untuk memabangkitkan serta menumbuhkan semangat dari seorang narapidana untuk berbuat baik dan sesuai dengan tujuan pemasyarakatan dan pembinaan. Menurut Schepper Maksud pembebasan bersyarat ialah mengembalikan terpidana ke dalam masyarakat untuk menjadi warga yang baik dan berguna (Hamzah, 2008).

Pengaturan pembebasan bersyarat diatur dalam KUHP dalam pasal 15, 15a, 15b, PP No. 99/2012 yang terdapat dalam pasal 43, 43A dan 43B selain itu juga diatur dalam PERMENKUMHAM No. 21/2013 dalam pasal 49. Menteri Hukum dan HAM mempunyai kewenangan untuk memberi pembebasan bersyarat sesuai dengan ketentuan undang-undang. Pembebasan bersyarat tersebut adalah suatu fungsi lembaga pemasyarakatan, yang merupakan salah satu dari bagian sistem peradilan pidana Indonesia, yaitu Kepolisian, Kejaksaan, dan Pengadilan (Pandjaitan \& Widiarty, 2008). Dalam hal bimbingan dan pembinaan bagi seorang Narapidana yang sedang mengikuti proses pembebasan bersyarat dilakukan oleh Balai Pemasyarakatan (BAPAS). Pengawasan terhadap pembebasan bersyarat selain dilakukan oleh BAPAS juga dilakukan oleh Kejaksaan. Menurut hasil wawancara pada tanggal 11 Januari 2018 dengan Ibu Titiek Sudaryatmi, Bc. IP, S.H., M.Si selaku Kepala Bapas di Balai Pemasyarakatan Kelas I Denpasar, petugas Pembimbimbing Kemasyarakatan (PK) dalam mencari persetujuan kesanggupan dari pihak keluarga dan aparat pemerintah setempat tersebut dilakukan dengan cara penelitian langsung ke keluarga narapidana dan aparat pemerintah setempat yakni kelian dinas atau kepala desa, proses penelitian tersebut bernama LITMAS (Penelitian Kemasyarakatan)

\section{Peran Keluarga sebagai Penjamin dalam Pemberian Pembebasan Bersyarat Kepada Narapidana}

Selanjutnya dijelaskan bahwa persetujuan keluarga menjadi syarat wajib bagi seorang narapidana yang akan mendapatkan pembebasan bersyarat, apabila keluarga tidak mau memberi persetujuan dan tidak mau menjadi penjamin bagi narapidana yang mengajukan pembebasan bersyarat maka usulan pembebasan bersyarat tersebut ditolak dan tidak dapat diproses. Persetujuan keluarga menjadi syarat wajib dikarenakan keluarga yang akan mempertanggungjawabkan dalam hal membimbing dan mengawasi narapidana tersebut apabila telah mendapatkan Pembebasan Bersyarat. keluarga juga akan menjamin baik buruknya dari narapidana tersebut dan setelah keluar Surat Keputusan (SK) pembebasan bersyarat bagi narapidana harus wajib lapor dan mendapatkan bimbingan di Balai Pemasyarakatan, dikarenakan narapidana yang bersangkutanlah yang harus rutin melapor dan mendapatkan bimbingan di Balai Pemasyarakatan setiap bulannya dan tidak bisa diwakilkan oleh siapapun dan apabila narapidana yang mendapatkan pembebasan bersyarat tidak melapor ke Balai Pemasyarakatan, Pembimbing Kemasyarakatan akan meminta informasi tentang keadaan narapidana tersebut ke keluarga narapidana tersebut. Beliau juga menambahkan peran dan fungsi dari keluarga dalam proses pembebasan bersyarat selain memberikan informasi tentang keadaan dari narapidana yang menjalani proses pembebasan bersyarat, keluarga juga wajib membantu keadaan ekonominya dikarenakan setiap narapidana yang baru mendapatkan pembebasan bersyarat pada umumnya belum memiliki pekerjaan.

Menurut Ibu Titiek Sudaryatmi jika keluarga sebagai penjamin tidak melaksanakan kewajibannya dalam membimbing dan mengawasi narapidana yang berada bawah pengawasannya, 
penjamin tersebut tidak akan dikenakan sanksi karena belum ada peraturan perundang-undangan yang mengatur secara khusus fungsi penjamin serta sanksi bagi penjamin narapidana yang lalai dalam melaksanakan kewajibannya untuk membimbing dan mengawasi narapidana saat proses pembebasan bersyarat. Beliau menambahkan jika ada sanksi yang mengatur tentang kelalaian menjadi seorang penjamin untuk narapidana maka program pembebasan bersyarat bagi narapidana tidak akan bisa berjalan dikarenakan semua keluarga narapidana akan takut menjadi penjamin dan tentu saja menolak menjadi penjamin bagi seorang narapidana yang ingin mendapatkan pembebasan bersyarat.

Selain persetujuan keluarga yang menjadi syarat wajib bagi narapidana yang ingin mendapatkan pembebasan bersyarat juga perlu pesetujuan dari aparat desa setempat yakni kelian dinas atau kepala desa dimana penjamin yang akan menjamin narapidana tersebut bertempat tinggal. Persetujuan keluarga saja tidaklah cukup untuk mendapatkan pembebasan bersyarat. Persetujuan keluarga dan aparat pemerintah setempat bersifat wajib tidak dapat dipisahkan, menurut Ibu Titiek Sudaryatmi bahwa apabila salah satu pihak saja baik dari pihak keluarga maupun dari pihak kelian dinas atau kepala desa tidak menyetujui usulan pemberian pembebasan bersyarat maka pembebasan bersyarat narapidana tersebut tidak dapat diteruskan atau ditolak. Beliau menambahkan peran dari pemerintah setempat dimana penjamin narapidana tinggal sebagai perwakilan dari masyarakat sekiar di lingkungan tersebut. Selaku aparat pemerintah setempat harus mengetahui warganya yang bermasalah dengan hukum supaya nantinya pihak pemerintah setempat bisa memberikan bimbingan dan pengawasan bagi warganya yang bermasalah dengan hukum dan juga apabila narapidana yang menjalani pembebasan bersyarat melanggar hukum maka aparat pemerintah setempatlah yang akan dimintai keterangan terlebih dahulu mengenai prilaku narapidana yang melanggar hukum saat menjalani proses pembebasan bersyarat untuk dipakai pertimbangan pencabutan pembebasan bersyarat dari narapidana tersebut.

\section{SIMPULAN DAN SARAN}

\section{Simpulan}

Berdasarkan hasil dari pembahasan di atas, dapat disimpulkan bahwa pengaturan pembebasan bersyarat kepada narapidana diatur dalam Pasal 15, 15a, 15b dan 16 buku kesatu bab II Kitab Undang-Undang Hukum Pidana (KUHP) yang mengatur tentang pemberian narapidana pembebasan bersyarat, pencabutannya, penahanannya. Selain ketentuan yang terdapat dalam KUHP pengaturan pembebasan bersyarat diatur dalam pasal 1 angka 8 dan angka 9 PP No. 99/2012 mengenai perubahan kedua atas PP No. 32/1999 tentang Syarat dan Tata Cara Pelaksanaan Hak Warga Binaan Pemasyarakatan (PP No. 99/ 2012). Dalam Pasal 1 angka 8 dan angka 9 PP No. 99/2012 yang mengatur mengenai syarat-syarat dan prosedur pembebasan bersyarat, serta Peraturan Menteri Hukum Dan Hak Asasi Manusia No. 21/2013 tentang Syarat dan Tata Cara Pemberian Remisi, Asimilasi, Cuti Mengunjungi Keluarga, Pembebasan Bersyarat, Cuti Menjelang Bebas, dan Cuti Bersyarat yang mengatur lebih jelas tentang syarat-syarat dan prosedur mengenai pembebasan bersyarat. Kemudian, keluarga sebagai penjamin menjadi syarat wajib bagi seorang narapidana yang yang akan mendapatkan pembebasan bersyarat dikarenakan peran dan fungsi keluarga yang akan mempertanggung jawabkan dalam hal membimbing dan mengawasi narapidana tersebut apabila telah mendapatkan Pembebasan Bersyarat saat berada di Lembaga Pemasyarakatan dan selain hal tersebut, setelah keluar Surat Keputusan (SK) Pembebasan Bersyarat bagi narapidana harus wajib lapor dan mendapatkan bimbingan di Balai Pemasyarakatan.

\section{Saran}

Berdasarkan simpulan tersebut di atas maka dapat diajukan saran yakni: disarankan kepada Pemerintah yang berwenang dalam membuat peraturan mengenai pembebasan bersyarat agar mempermudah syarat dalam pemberian pembebasan bersyarat dalam hal menjadikan keluarga sebagai penjamin wajib dalam pengajuan pembebasan bersyarat dikarenakan masih ada keluarga yang tidak mau menjadi penjamin untuk narapidana dikarenakan alasan tertentu seperti menganggap bahwa narapidana tersebut kelakuannya masih sama seperti saat dipidana walaupun narapidana tersebut sudah berkelakuan baik di dalam Lapas, setiap manusia pasti mempunyai kesempatan untuk memperbaiki diri sesuai dengan tujuan pemasyarakatan, diharapkann dalam prakteknya selain keluarga, agar dapat dibentuk organisasi dari pemerintah maupun dari masyarakat dapat menjadi penjamin selain keluarga selain bertujuan untuk mewujudkan tujuan pemasyarakatan dan pembinaan 
narapidana di luar lembaga pemasyarakatan, pembebasan bersyarat juga dapat mengurangi kapasitas narapidana di lembaga pemasyarakatan yang sudah melebihi kapasitas dan mengurangi anggaran negara dalam mengurus narapidana. Kemudian, diharapkan kepada keluarga sebagai penjamin untuk lebih aktif menerima usulan pembebasan bersyarat dan membimbing serta mengawasi narapidana dalam proses pembebasan bersyarat, serta tak luput juga yakni masyarakat yang diwakili oleh pemerintah setempat juga turut serta berperan aktif dalam membimbing, mengawasi dan mengawal berlangsungnya proses pembebasan bersyarat guna mensukeskan tujuan pemasyarakatan. Melakukan kegiatan penyuluhan terhadap masyarakat juga perlu dilakuakan guna masyarakat lebih mengerti serta memahami pentingnya proses pembebasan bersyarat, khususnya di dalam lingkungan tempat narapidana yang menjalani proses pembebasan bersyarat.

\section{DAFTAR PUSTAKA}

Datunsolang, A. (2013). Perlindungan Hak Asasi Manusia Bagi Narapidana dalam Sistem Pemasyarakatan (Studi Kasus Lembaga Pemasyarakatan Kelas II A Manado). Jurnal Hukum UNSRAT, 21(4), 111-123.

Hamzah, A. (2008). Asas-asas Hukum Pidana. Rineka Cipta.

Jufri, E. A., \& Anisariza, N. U. (2018). Pelaksanaan Asimilasi Narapidana di Lembaga Pemasyarakatan Terbuka Jakarta. ADIL: Jurnal Hukum, 8(1), 1-26.

Kusuma, F. P. (2013). Implikasi Hak-Hak Narapidana dalam Upaya Pembinaan Narapidana dalam Sistem Pemasyarakatan. Recidive, 2(2), 102-109.

Pandjaitan, P. I., \& Widiarty, W. S. (2008). Pembaharuan pemikiran DR.Sahardjo Mengenai Pemasyarakatan Narapidana. Indihill Co.

Putra, A. R. A. A., \& Puspita Sari, N. (2013). Kendala Pemberian Pembebasan Bersyarat di Lembaga Pemasyarakatan Kelas IIa Sragen. Jurnal Recidive, 2(3), 280-289.

Samosir, C. D. (2016). Penologi dan Pemasyarakatan (Cetakan Pe). Nuansa Aulia.

Soekanto, S. (2007). Pengantar Penelitian Hukum. UI Press.

Utami, P. N. (2017). Keadilan Bagi Narapidana di Lembaga Pemasyarakatan. Jurnal Penelitian Hukum De Jure, 17(3), 381-394.

Undang-Undang Nomor 12 Tahun 1995 tentang Pemasyarakatan. Lembaran Negara Republik Indonesia Tahun 1995 Nomor 77. Tambahan Lembaran Negara Republik Indonesia Nomor 3614

Peraturan Pemerintah No. 99 Tahun 2012 tentang Perubahan Kedua Atas Peraturan Pemerintah No. 32 Tahun 1999 tentang Syarat dan Tata Cara Pelaksanaan Hak Warga Binaan Pemasyarakatan. Lembaran Negara Republik Indonesia Tahun 2012 Nomor 225. Tambahan Lembaran Negara Republik Indonesia Nomor 5359

Peraturan Menteri Hukum Dan Hak Asasi Manusia Republik Indonesia No. 21 Tahun 2013 tentang Syarat Dan Tata Cara Pemberian Remisi, Asimilasi, Cuti Mengunjungi Keluarga, Pembebasan Bersyarat, Cuti Menjelang Bebas, Dan Cuti Bersyarat. Berita Negara Republik Indonesia Tahun 2013 Nomor 832

Peraturan Menteri Hukum dan Hak Asasi Manusia Nomor 21 Tahun 2016 tentang Perubahan Atas Peraturan Menteri Hukum dan Hak Asasi Manusia No. 21 tahun 2013 tentang Syarat dan Tata Cara Pemberian Remisi, Asimilasi, Cuti Mengunjungi Keluarga, Pembebasan Bersyarat, Cuti Menjelang Bebas dan Cuti Bersyarat. Berita Negara Republik Indonesia Tahun 2016 Nomor 810 